\title{
On the Educational Reform of College Accounting against the backdrop of Strengthened Ideological Education
}

\author{
Hui WEN ${ }^{1, a}$ and Ling-Bo ZENG ${ }^{1, b^{*}}$
}

${ }^{1}$ Department of Financing and Auditing, Military Academy of Logistic Service, No.122, Luo Jiadun, Qiaokou District, Wuhan City, Hubei Province, 430035, PRC

a375081403@qq.com; ${ }^{\text {b, }}$ 1844088505@qq.com

Keywords: ideological education; accounting; educational reform; quality-oriented education; innovation

Abstract: The $19^{\text {th }}$ National Congress of the Communist Party of China proposed that the fundamental task of ideological education of the higher education with Chinese characteristics should be implemented effectively and quality-oriented education be developed steadily. Compared with the new standard of ideological education in the new era, there are still many problems to be solved in accounting education. This paper makes a brief analysis of problems faced with accounting education in China's colleges and universities under the demand of strengthened ideological education in the new situation, and tries to put forward some corresponding countermeasures of reform to better develop the discipline of accounting in China.

\section{Introduction}

The higher institutions undertake the important task of cultivating high-quality talents for the country, and the education of accounting in colleges or universities shoulders the mission of cultivating accounting professionals with both political integrity and professional competence for the society. The Report presented by China's President Xi at the $19^{\text {th }}$ National Congress of the Communist Party of China stressed that the educational guidelines of the Party should be carried out in an all-round way, quality-oriented education should be conducted vigorously, and socialist builders and successors featuring an all-round development in morality, intelligence, physique and art should be cultivated by strengthening the ideological education of the students at colleges and universities in the country[1]. Under such a new background, how to incorporate the ideological education into the professional education of accounting has become a brand-new subject for Chinese colleges and universities. As is generally acknowledged, ideological education is not pure infusion of knowledge, but a significant link in the chain of the education of values, faculty and quality for the students. Therefore, it's of great importance to discuss how to improve the accounting majors' cognitive ability of their occupations in the future and literacy of their professional ethics in order to enhance their professional quality and all-round development.

\section{Problems Faced with the Current Accounting Education}

\subsection{Lack of Innovation in Educational Philosophy}

As early as in 2013, President Xi had mentioned that, innovation serves as the soul of the national progress and endless source of prosperity of the country[2]. The innovative talents have become unprecedentedly important for any country in the $21^{\text {st }}$ century, because the competition in the field comprehensive national strength often finally falls on its innovative competence. Of course, the cultivation of innovative talents mainly comes from education, especially the higher education. At present, accounting education in China, however, is often in serious lack of innovation for many reasons. One of the most important reasons is we still focus on the instrumental and service needs of accounting in college education, taking little into consideration the societal and professional needs, like the professional ethics for them in the future. Such an educational philosophy has so far deeply influenced the students' ability in researching, analyzing and solving problems in their future careers. 


\subsection{Undiversified Educational Tools and Methods}

Accounting, quite different from other courses like Literature, History, is dripping with terms and theoretical knowledge, which makes the learners feel bored and difficult[3]. So how to make it more understandable and interesting relies on the educational tools teachers resort to and the educational methods employed by the teachers. However, the fact at present is that in the accounting class, teachers usually play a dominant role, they act as the leading actors who offer knowledge, while the students are only the listeners. Case study and heuristic methods are seldom conducted for different reasons. The students often know well after graduation how to deal with the work professionally, but they don't know how to do the job righteously for lack of ideological education when they were in colleges.

\subsection{Incomplete Curriculum System}

Years ago, it was believed that ideological education had nothing to do with other courses, so courses like accounting don't have an ounce of business with ideological education. The current defect of the course caused by this curriculum system is that in most of today's accounting textbooks, either Foundations of Accounting, Financial Accounting, Management Accounting or Cost Accounting, or Military Accounting, knowledge like professionalism of accounting is quite limited. For some with a handsome of amount in this specific aspect, the cases mentioned often cannot follow the rapid change of times either, or the teachers may choose to skip it because of class time limit. It's no wonder that the graduates tend to be very skilled in doing their professional jobs with little professionalism.

\subsection{Unsound Evaluation Mechanism}

Another problem faced with accounting education in Chinese colleges or universities is that its the evaluation system for students is still far from sound. For examinations on the accounting course, the focus is often laid on the students' academic performance in the final examination with most questions are multiple choices or questions and answers, the students' research ability is often not on the agenda of the examinations. In other words, the evaluation mechanism is more summative than formative, with more stress put on the results of the final examinations, while the students' attitudes to study and their professional ethics formed during the whole process are subject to neglect.

\section{Countermeasures on the Current Accounting Education}

\subsection{Innovating the Teaching Philosophy}

Undoubtedly, ideological education should be integrated into the teaching philosophy of accounting. As is generally held, teaching of knowledge and cultivating of character is inseparable from each other. For the accounting course, both imparting of professional knowledge and cultivating of work ethics are important for the all-round development of students. College years is the critical period for the formation of students' world outlook, and their outlook on life and value. Therefore, Chinese colleges and universities should spare no efforts to innovate their teaching philosophies. Actually, top universities like Tsinghua University has formed an advanced set of teaching philosophy, namely, Trinity, Integration of Liberal Education and Speciality Education, Diversified Development of Students. Trinity here refers to the union of shaping of value, cultivating of ability and imparting of knowledge. The first priority is given to the forming of students' value system[4]. We maintain that all Chinese colleges and universities can learn something from the teaching philosophy of Tsinghua University so that the talents cultivated for the society really fit the development of our country and they will well serve our country with great responsibilities and professionalism.

Meanwhile, synergistic effect between accounting course and ideological education should be created. In December 2016 at the National Conference on College Ideological and Political Work, President Xi pointed out that, different courses at colleges should shoulder their own responsibilities, 
all other courses should parallel with the course of ideological education, so that the synergistic effect would be finally reached[5]. Ideological education should be carried out synchronously with Accounting education in today's China too. Although they have quite different features, the final educational purpose of all courses is the same, that is, cultivating socialist talents with tested ideological and political quality, sound personality, scientific mode of thinking as well as hard innovative and practical abilities. In the accounting course, education on the industry ethics and personal professionalism are quite necessary for students in the future to be clean and responsible financial workers.

\subsection{Updating the Teaching Content}

In the first place, materials on occupational standards and codes should be supplemented into the current teaching of accounting. If so, not only the students' level of ideological education will be improved, but they will broaden their horizons after systematic learning of the knowledge in the specific fields of Financing, Auditing, Taxation Law, etc. Ultimately, the accounting-related work will be done better in our society.

Secondly, integration between the occupational standard and speciality courses should be further promoted. Take the Foundations of Accounting for example. It is the very fundamental course for every student majoring in Accounting of Financing. If they can learn some basic knowledge of the occupational standard at the very beginning, they would be more faithful to their duties, more honest, cleaner, and work more morally in the future as accountants[6].

\subsection{Reforming the Teaching Modes and Methods}

Suffice it to say, the teaching concepts and methods are extremely important for cultivation of accounting talents. In the past, a lot of accounting talents cultivated by colleges are not qualified for the society, mainly because they don't know what they really want from each other. In this sense, it's important to strengthen the cooperation between colleges and relevant industries or companies. The students before graduation should be sent to corresponding companies for an internship to better know their own qualifications and the social expectations of them. On the other hand, experienced accountants from specific industries or companies can walk into college to know the present situation of accounting education, exerting some influence on the educational mode of talents if necessary. In a word, all parties in the society should work together to improve the educational level of accounting.

Furthermore, new teaching methods like case study should be used more widely in college education of accounting. Through the extended example of how some accountants commit crimes in their profession for not knowing the importance of being clean and law-abiding, students may be more conscious of their study of professional standard and moral ethics. Then, they may have better understanding and mastery of ideological education for them.

\subsection{Redesigning A Set of Multi-dimensional Evaluation Mechanism}

Formative evaluation, if not more important, then is the same important as the summative evaluation. Students' attitudes toward study, the efforts they make to cultivate their characters and take the initiative to do something more responsibly will be of great importance for them in their occupations in the future. Such factors are difficult to be quantified, but they may determine an accountant's job in the future. So redesigning a set of multi-dimensional evaluation mechanism should be fully considered.

\section{Conclusion}

On the whole, reform of accounting education under the background of strengthened ideological education is a complicated and huge program. It touches upon quite a few factors. This program puts forward a higher requirement for the students who should work hard in different aspects, including their ideological and political awareness and sensitivity. Also, it's becoming more and more difficult for the teachers too, because they should not only focus on the teaching of 
professional knowledge to the students, but also how to effectively improve and reform their teaching materials and methods, paying due attention to the constructive education of ideology in the new era. Only when ideological education is integrated into other courses like accounting in a well designed and embedded way, it will reap more benefits in building young students into qualified talents by our country.

\section{References}

[1] Xi Jinping, To Build a Moderately Prosperous Society in all Respects and Seize the Great Victory of Socialism with Chinese Characteristics in the New Era, In Chinese[DB/OL]. http://cpc.people.com.cn/n1/2017/1028/c64094-29613660.html.

[2] Xi Jinping's Speech to the Excellent Youth Representatives from all Walks of Life, In Chinese[DB/OL]. http://cpc.people.com.cn/n/2013/0505/c64094-21367227.html.

[3] Jin Caiyun, Research on the Innovative Cultivating Mode of Accounting Talents, In Chinese[J]. Study and Innovation, 2011, 9:43-44.

[4] Seminar on the Educational Philosophy of Tsinghua was Held in Tsinghua University, In Chinese[DB/OL].http://www.tsinghua.edu.cn/publish/thunews/9649/2017/20171101135756628725 710/20171101135756628725710_.html.

[5] Xi Jinping, Ideological and Political Education Should Run Through the Whole Process of Higher Education, In Chinese[DB/OL].

http://dangjian.people.com.cn/n1/2016/1209/c117092-28936962.html.

[6] leng Lin, Rao Zhiying, On How to Incorporate Ideological Education into Intermediate Financial Accounting, In Chinese[J]. Finance and Accounting Monthly, 2011, 11:107-108. 